\title{
MANAJEMEN MUTU DALAM PERSPEKTIF ISLAM
}

\author{
DIAN, ANISA WAHYUNI \\ Pascasarjana Universitas Islam Negeri Sunan Gunung Djati Bandung \\ Email: diankutunggu@gmail.com
}

\begin{abstract}
:
This paper supports to explain the concept of quality management in Islamic perspective. Improvement efforts in simple educational institutions that are carried out continuous improvement. In order to produce quality educational outputs, the elements involved in education are also needed, competitive and efficient. Improving the quality of education is the first step that needs to be done. Quality must always get the attention and support of various parties. Therefore, quality management is needed in the development of professional Islamic educational institutions as an answer to these problems, especially in the context of educational autonomy today. For this reason, in order to improve the quality of Islamic educational institutions, they need to be assisted, defended, championed to be able to live and develop.
\end{abstract}

Keywords: Management, Quality, Islam

\section{PENDAHULUAN}

$\mathrm{P}$ ada era globalisasi yang penuh dengan tantangan saat ini, pelayanan mutu menjadi salah satu fokus lembaga pendidikan untuk tetap menjaga eksistensi dan mampu bersaing secara kompetitif agar tetap tumbuh dan berkembang. Secara umum, mutu adalah gambaran dan karakteristik menyeluruh dari bidang atau jasa yang bertujuan untuk memuaskan kebutuhan konsumen. Suatu barang atau jasa dapat dikatakan bermutu oleh seorang konsumen, tetapi konsumen yang lain belum tentu mengatakan hal yang sama (Jaja Jahari, 2013).

Dalam konteks pendidikan, mutu mencakup input, proses dan output pendidikan. Input pendidikan adalah karakteristik yang tersedia pada sebuah lembaga pendidikan karena dibutuhkan untuk berlangsungnya proses sumber daya yang meliputi sumber daya manusia (guru, staf dan peserta didik) dan sumber daya lainnya (sarana dan prasarana, peralatan, perlengkapan, dana dan lain-lain). Kesiapan input sangat berpengaruh bagi lembaga pendidikan agar proses pelayanan mutu dapat berjalan dengan baik. Tinggi atau rendahnya kesiapan input dapat dilihat dari tingkat kesiapan input. Semakin tinggi kesiapan input maka semakin tinggi pula mutu dari input tersebut (Abdullah, 2014).

Islam merupakan agama yang universal, yang mencakup ibadah aqidah dan muamalah baik dalam kehidupan individual maupun kehidupan sosial. Islam mengajarkan bahwa dalam melakukan suatu pekerjaan perlu perencanaan yang baik, terukur dan terarah sebagaimana dalam Surat As-Sajdah: 5. Pendidikan islam 
merupakan sistem yang terpadu karena pendidikan islam mengandung konsep keimanan dan ketakwaan selain ilmu pengetahuan.

\section{PEMBAHASAN}

\section{Konsep Manajemen}

Manajemen adalah usaha untuk mencapai sebuah tujuan melalui kegiatan orang lain. Manajemen adalah sebuah proses yang harus dilakukan untuk mencapai tujuan tertentu yang memerlukan suatu perencanaan, pemikiran, pengaturan dan pengarahan agar dapat berjalan dengan baik serta memerlukan penggabungan seluruh potensi yang ada secara efektif dan efisien (Badrudin, 2014).

Manajemen sering dipandang sebagai sebuah ilmu, kiat dan profesi yang keseluruhannya dilakukan agar mencapai tujuan diantaranya yaitu, bagaimana cara bekerja sama dengan orang lain, bagaimana bekerja secara sistematis sehingga mampu mencapai sasaran serta bagaimana bekerja secara profesional.

Pada umumnya, manajemen sering dikaitkan dengan perencanaan, pengorganisasian, penempatan, pengendalian, pemotivasian, pengarahan, pengambilan keputusan dan komunikasi yang dilakukan oleh sebuah organisasi yang bertujuan mengkoordinasikan berbagai sumber daya yang ada sehingga akan menghasilkan sebuah jasa atau produk yang efisien (Prihatin, 2011). Maka kesimpulannya adalah manajemen memerlukan berbagai aktivitas yang keseluruhannya dilakukan untuk mencapai tujuan yang telah dibuat melalui keputusan bersama.

Manajemen bertujuan agar pelaksanaan dari suatu usaha dapat terencana secara sistematis sehingga dapat dievaluasi dengan benar dan akurat sehingga memungkinkan sebuah organisasi untuk mencapai tujuannya secara efektif, efisien, berkualitas dan produktif (Engkoswara, 2012). Tujuan manajemen harus tercapai secara efektif dan efisien, dalam artian bahwa keberhasilan seorang manajer diukur dari pencapaian tujuan organisasi secara efektif dan efisien. Drucker mempopulerkan istilah efisien sebagai doing thing right dan efektif sebagai doing the right things (Badrudin, 2014).

Manajemen bertujuan untuk mencapai sebuah tujuan tertentu melalui usaha yang terencana sehingga mendapatkan hasil yang maksimal secara efektif dan efisien. Efisien adalah kemampuan menggunakan sumber daya dengan benar, walaupun sumber daya yang ada sangat terbatas namun hal tersebut dapat dimanfaatkan dengan benar berdasarkan fungsinya masing-masing sedangkan efektif merupakan kemampuan mengerjakan sesuatu dengan benar dan sistematis. Efektivitas sangat berkaitan dengan tujuan karena semakin dekat organisasi atau lembaga kepada tujuannya maka semakin efektif organisasi atau lembaga tersebut.

Hadirnya manajemen dalam sebuah organisasi adalah untuk melaksanakan sebuah kegiatan agar mencapai sebuah tujuan secara efektif dan efisien. Secara tegas tidak ada rumusan yang sama dan berlaku umum untuk fungsi manajemen. 
Akan tetapi fungsi manajemen dapat ditelaah dari aktivitas-aktivitas utama yang dilakukan oleh para manajer (Engkoswara, 2012).

\section{Manajemen Mutu}

Mutu merupakan topik yang aktual dalam bidang bisnis, pendidikan maupun bidang-bidang lainnya. Namun istilah mutu memerlukan tanggapan secara hati-hati dan memerlukan penafsiran yang cermat. Penerapan manajemen mutu dalam pendidikan mengutamakan pencapaian harapan pelanggan melalui upaya perbaikan secara terus menerus. Banyak sekali pakar dalam manajemen mutu memberikan batasan mutu yang berbeda-beda. (Saud, 2018).

Istilah mutu menunjukkan kepada sebuah ukuran penilaian atau penghargaan yang diberikan atau dikenakan kepada barang atau kinerjanya. Mutu memiliki makna ukuran, kadar, ketentuan dan penilaian tentang kualitas suatu barang maupun jasa (Basyit, 2018).

Mutu merupakan keseluruhan karakteristik produk dan jasa yang meliputi marketing, engineering, manufacture dan maintanance dimana produk barang dan jasa tersebut dalam pemakaiannya akan sesuai dengan kebutuhan dan harapan stakeholders. Suatu produk dan jasa dikatakan bermutu apabila dapat memberikan kepuasan sepenuhnya kepada stakeholders (Saud, 2018).

Mutu merupakan suatu ide yang dinamis berkaitan dengan apa yang diinginkan oleh pelanggan yang menyangkut keseluruhan wujud barang atau jasa. Dengan demikian mutu memiliki standar yang seharusnya melampaui keinginan pelanggan.

Tujuan mutu adalah untuk menciptakan perubahan serta melakukan peningkatan secara terus menerus sehingga dapat memberikan kepuasan yang maksimal bagi pelanggan atau konsumen. Selain itu, mutu bertujuan untuk meyakinkan pelanggan bahwa produk atau jasa yang ditawarkan telah memenuhi syarat dan dapat memberikan kepuasan bagi pelanggan.

Manajemen mutu merupakan salah satu cara yang dapat memfasilitasi kebanyakan ahli atau profesional pendidikan memecahkan permasalahan lingkungan pendidikan khususnya yang terus statis. Manajemen mutu dapat dioperasikan sebagai perantara untuk membentuk jalinan antara dunia pendidikan, bisnis, dan penguasa (Mahmudin, 2018).

Secara filosofis, konsep manajemen mutu menekankan pada pencarian secara konsisten terhadap perbaikan yang berkelanjutan untuk mencapai kebutuhan dan kepuasan pelanggan. Strategi yang dikembangkan dalam penggunaan manajemen mutu dalam dunia pendidikan adalah institusi pendidikan memposisikan dirinya sebagai institusi jasa atau dengan kata lain menjadi industri jasa. Yakni institusi yang memberikan pelayanan (service) sesuai dengan apa yang diinginkan pelanggan (costumer) (Basyit, 2018).

Tujuan manajemen mutu yaitu untuk memastikan bahwa seluruh sumber daya manusia dalam sebuah instansi atau organisasi telah bekerja sama untuk 
meningkatkan kualitas secara maksimal sehinggga dapat mencapai kepuasan konsumen dan berdampak pada keberhasilan jangka panjang.

\section{Komponen Manajemen Mutu}

Mutu sebuah lembaga atau organisasi tidak akan menjadi baik apabila sebuah lembaga atau organisasi tersebut tidak mampu memenuhi komponen mutu itu sendiri. Maka dari itu, terdapat empat komponen mutu yang harus dipenuhi agar mencapai sebuah mutu (Jaja Jahari, 2013). Keempat komponen tersebut yaitu:

a. Perencanaan Kualitas

Perencanaan kualitas merupakan proses untuk mengidentifikasi standar kualitas yang relevan dengan jasa serta membuat keputusan tentang cara untuk mencapainya.

b. Peningkatan Kualitas

Untuk meningkatkan kualitas maka lembaga pendidikan harus melakukan perubahan yang disengaja sehingga mereka mendapatkan kepercayaan dan kepuasan jasa.

c. Kualitas Kontrol

Salah satu upaya yang terus menerus dalam menjaga mutu adalah dengan menegakkan integritas dan juga kehandalan proses untuk mencapai hasil.

d. Jaminan Kualitas

Dengan adanya kegiatan yang dilakukan secara sistematis dan terencana maka dapat memberikan jaminan kualitas pada produk atau jasa layanan.

\section{Manajemen Mutu Dalam Perspektif Islam}

Manajemen mutu mempunyai relasi yang sangat kuat dengan apa yang diajarkan Islam di dalam Alquran dan hadits. Namun dalam penerapannya, umat Islam kalah jauh dengan orang-orang non-muslim yang justru tidak mengetahui seluk beluk isi kandungan Al-Quran dan hadis. Demikian juga menciptakan segala sesuatu yang ada baik di langit maupun di bumi (Basyit, 2018).

Islam mengajarkan agar setiap manusia ketika mengerjakan segala sesuatu harus itqan artinya bersungguh-sungguh, teliti, tidak sesetengah-setengah dan sepenuh hati sehingga pekerjaan menjadi rapih, indah, tertib, dan sesuai dengan yang diperintahkan atau yang seharusnya terjadi (Mahmudin, 2018).

Maksud dari hal tersebut yaitu agar dapat memberikan kebaikan dalam artian mampu memuaskan pelanggan. Tentunya melalui tahapan-tahapan yang berkesinambungan diantaranya yaitu: proses yang bermutu. Proses yang bermutu dapat dilakukan apabila sumber daya manusia bekerja secara optimal, mempunyai komitmen dan istiqomah dalam pekerjaannya.

Tanpa adanya komitmen dan istiqomah dari sumber daya manusia di sebuah instansi atau organisasi maka instansi atau organisasi tersebut tidak akan dapat melakukan proses yang bermutu. Maka dari itu untuk melakukan proses yang bermutu dibutuhkan sumber daya manusia yang bermutu serta berdedikasi tinggi. 
Proses yang bermutu perlu dilakukan oleh seluruh jenjang dan seluruh lini dalam sebuah instansi atau organisasi. Apabila seluruh sumber daya manusia dalam instansi dan organisasi menyadari pentingnya hal tersebut, maka mutu sebuah instansi atau organisasi tersebut dapat tercipta.

Ketika bekerja, sumber daya manusia dituntut untuk tidak memandang sepele bentuk-bentuk kerja yang dilakukan, memberi makna kepada pekerjaannya tersebut, sadar bahwa amal adalah mode of existence dan dari sisi efeknya, amal itu bukan diperuntukkan untuk Tuhan, namun untuk dirinya sendiri (Mahmudin, 2018).

Kita sebagai makhluk ciptaannya ketika mengerjakan sebuah kegiatan yang baik, maka Allah akan memberikan ganjaran atau imbalannya untuk siapa yang mengerjakannya, namun apabila kita sebagai hambanya melakukan sebuah kejahatan, maka dosa dan azab dari Allah akan menimpa kita.

\section{PENUTUP/SIMPULAN}

Kepuasan konsumen merupakan salah satu kunci untuk menciptakan hubungan yang baik dengan konsumen sehingga dapat berpengaruh pada keberhasilan jangka panjang. Mutu merupakan segala sesuatu yang menjadi kebutuhan dan keinginan konsumen. Manajemen mutu adalah sebuah sistem manajemen yang berfungsi untuk mengawasi kegiatan dan tugas untuk memastikan bahwa produk atau jasa yang diberikan telah maksimal sehingga dapat menciptakan kepuasan konsumen. Manajemen mutu pendidikan dalam perspektif islam memerlukan manajemen yang tepat. Upaya untuk melaksanakan peningkatan mutu pendidikan diperlukan beberapa dasar yang kuat.

\section{DAFTAR PUSTAKA}

Abdullah, S. R. 2014. Implementasi Manajemen Mutu. Bandung: UIN Sunan Gunung Djati.

Badrudin. 2014. Manajemen Peserta Didik. Jakarta: Indeks.

Basyit, A. 2018. Implementasi Manajemen Mutu Pendidikan Islam. KORDINAT: Jurnal Komunikasi Antar Perguruan Tinggi Agama Islam, 187-210.

Engkoswara. 2012. Administrasi Pendidikan. Bandung: Alfabeta.

Jaja Jahari, A. S. 2013. Manajemen Madrasah Teori, Strategi dan Implementasi. Bandung: Alfabeta.

Mahmudin, H. I. 2018. Manajemen Mutu Terpadu dalam Perspektif Pendidikan Islam. Seminar Nasional (pp. 143-152). Bogor: Universitas Ibnu Khaldun.

Prihatin, E. 2011. Teori Administrasi Pendidikan. Bandung: Alfabeta.

Saud, U. S. 2018. Bunga Rampai Administrasi Pendidikan Teori dan Praktik. Bandung: Alfabeta. 